Original Research Paper

\title{
Review on the use of FRP Composites for Façades and Building Skins
}

\author{
Chiara Bedon \\ Department of Engineering and Architecture, University of Trieste, Trieste, Italy
}

Article history

Received: 24-08-2016

Revised: 28-09-2016

Accepted: 29-09-2016

Corresponding Author:

Chiara Bedon

Department of Engineering and

Architecture, University of

Trieste, Trieste, Italy

Email: bedon@dicar.units.it

\begin{abstract}
Fiber Reinforced Polymer (FRP) composites represent a class of materials typically able to offer excellent mechanical, thermal and insulation properties, taking advantage of a combination of their constitutive fibers and polymers. Due to their intrinsic lightweight properties, FRP composites are in use for aerospace, automotive, marine industries and ballistic armor since several decades. Only in a subsequent phase, i.e. since the late 1990s, FRP composites found application in civil engineering constructions, including both building systems and infrastructures, for retrofitting purposes in existing structural systems, as well as for pure architectural or structural purposes in novel assemblies. This review paper aims to highlight the most recent applications of FRPs in façades and building skins, with careful attention for case studies and novel design concepts.
\end{abstract}

Keywords: Fiber Reinforced Polymer (FRP) Composites, FRP Façades, Façade Retrofitting, Adaptive Façades, Shading Systems

\section{Introduction}

Fiber Reinforced Polymer (FRP) composites represents a family of materials combining fibers and polymers to offer excellent mechanical, thermal and insulation properties. As such, within the frame of civil engineering applications in buildings and infrastructures, FRP composites have been extensively investigated, especially in the last decade. The interaction of FRP composites with traditional construction materials like reinforced concrete, steel, timber or masonry assemblies has been in fact studied under a variety of loading conditions, including seismic loads as well as explosive events. In such cases, a primary importance has been given to the use of FRP composites in existing buildings structural systems for retrofitting and strengthening purposes.

The rehabilitation of buildings and civil engineering infrastructures is becoming even more important, due to the historical value of the built heritage. Compared to traditional construction materials for buildings, FRP composites represent a relatively novel construction solution with several intrinsic advantageous properties, such as high strength and stiffness, reduced mass, low thermal conductivity, high corrosion and weather resistance, durability, but also the implicit feature of offsite fabrication, modular construction capacity and possibility to mould complex forms with special finishes and effects (see Kendall, 2007 and Fig. 1). A direct consequence of such properties is that the use of FRP composites in novel façades and building skins is currently increasing, since due to absence of thermal bridges, the same FRPs further provide the opportunity to minimize (i.e. compared to traditional steel or aluminum-based façade systems) the basic components of the building skins themselves, hence contributing to the construction of curtain walls with high thermal performances and energy efficiency buildings.

In this sense, multiple typologies of applications emphasize the potential of FRP composites in façades. On one side, the retrofitting solutions for existing buildings are currently developing. At the same time, modern buildings are required to respect specific provisions in terms of thermal insulation performance, as well as to offer enhanced life performances (see for example (Gates et al., 2012). Finally, architectural trends in modern buildings are moving towards free-form shapes and increasing geometrical complexity for building envelopes (see for example (Paparo et al., 2015).

This review paper, in this context, aims to provide a brief state-of-the art review on some applications of FRPs in façades and building skins, with careful attention for some recent case studies and novel design concepts, giving evidence of current trends and possible research and industry developments.

\section{FRP Composites}

Fiber Reinforced Polymers (FRPs) represent a class of composite material made of a polymer matrix reinforced with fibers. The structural interaction between the basic components results in a composite of high performance in a multitude of applications. 


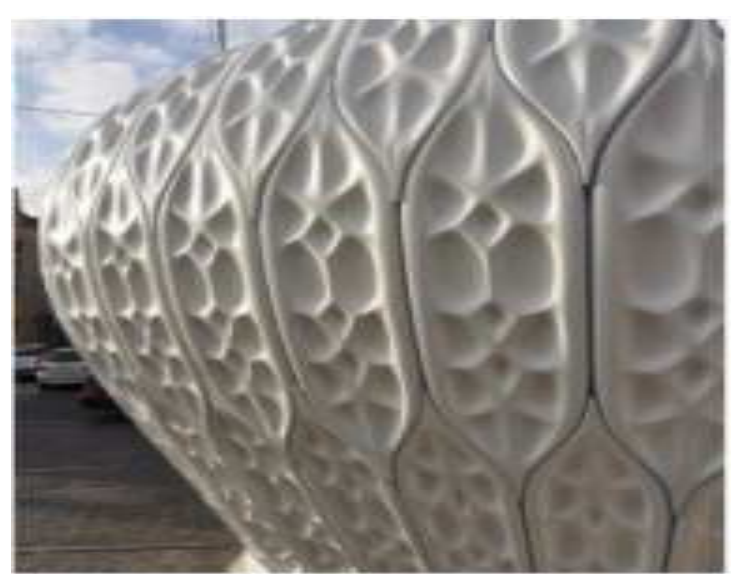

(a)

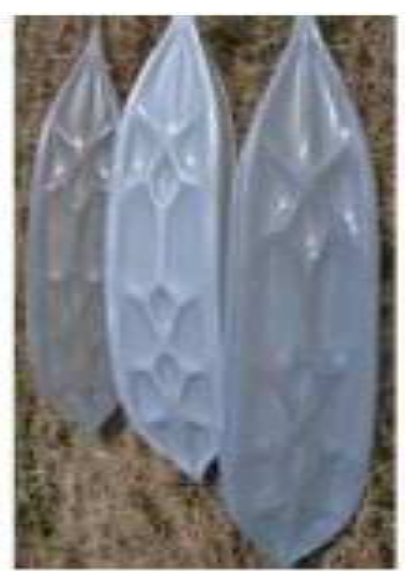

(b)

Fig. 1. FRP pavilion (Cocoon_FS project by Pohl Architects, www.pohlarchitekten.de). (a) Overview (b) Detail of the FRP petals. (ource: www.compositesworld.com)

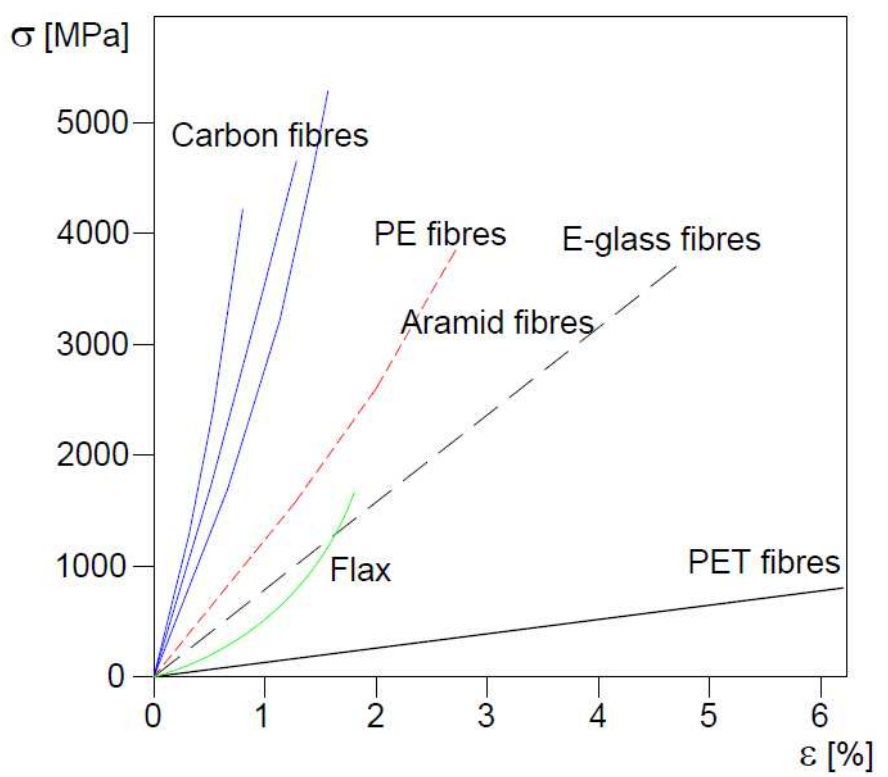

Fig. 2. Comparison of stress-strain constitutive laws for different types of fibers for application in FRP composites (Knippers et al., 2011)

While FRPs are commonly used in the aerospace, automotive, marine and construction industries and in ballistic armor, the trends of last decades emphasize a huge application of FRPs in civil engineering applications, both in the form of retrofitting solutions or novel architectural and load-bearing assemblies for buildings and infrastructures. Compared to traditional construction materials, fiber reinforced polymers offer a great potential in buildings. Literature research contributions as well as a continuously increasing number of case studies proved that FRP composites both in the form of sandwich elements, wraps and strips, pultruded profiles etc. - can act as load carrying components with excellent waterproof and thermal insulation components.
The fibers are essentially responsible of the loadbearing capacity and stiffness of the composite assembly, while the polymer's role consist in stabilizing and protect the fibers themselves.

These fibers are generally distinguished in inorganic (i.e., man-made, synthetic), organic, metal or natural fibers. Synthetic fibers are largely used in architectural applications, due to their typically high strength and durability.

Among the wide set of possibilities, see Table 1 and Fig. 2, the fibers of common use are glass (relatively inexpensive), carbon (typically stiffer than glass fibers), aramid or basalt (both characterized by typically high cost). Rarely, other fibers such as paper or wood or asbestos can be used. 
$\underline{\text { Table 1. Classification of fibers for application in FRP composites, depending on their origin (Knippers et al., 2011) }}$

\begin{tabular}{ll}
\hline Natural fibers & Organic fibers \\
\hline Flax & Polyethy (PE) \\
Sisal & Polyethylene Terephthalate (PET) \\
Hemp & Polyamide (PA) \\
Jute & Polymide (PI) \\
Ramie & Polyacrylonitrile (PAN) \\
Banana & Polytetrafluoroethylene (PTFE) \\
Asbestos & Aramid \\
\hline Metal fibers & Inorganic fibers \\
\hline Steel & Glass \\
Aluminum & Carbon \\
Copper & Basalt \\
& Ceramic \\
\hline
\end{tabular}

Table 2. Mechanical properties of polymers of common use for FRP composites (Knippers et al., 2011)

\begin{tabular}{lllll}
\hline Property/Type of polymer & UP & EP & VE & PF \\
\hline Density $\left[\mathrm{g} / \mathrm{m}^{3}\right.$ ] & 1.20 & 1.20 & 1.20 & 1.20 \\
Tensile strength [MPa] & $40-70$ & $60-125$ & $70-84$ & $20-60$ \\
Elastic modulus [GPa] & $3-4.2$ & $3-6$ & $3.4-3.6$ & $1.5-2.5$ \\
\hline
\end{tabular}

Legend: UP = Unsatured Polyester Resin; EP = Epoxy Resin; VE = Vinylester Resin; PF = Phenolic Resin

The polymer, asked to protect the fibers towards UV radiation and aggression of moisture or chemicals, as well as to ensure the required level of transparency for the fiber composite surface, is generally classified on the base of its molecular structure. Three main groups can be distinguished for polymers of typical use in fiber composites, i.e. thermoplastics, elastomers and thermosets.

Unsaturated Polyester Resin (UP), Epoxy Resin (EP), Vinylester Resin (VE) and Phenolic Resin (PF) are in widespread use in the building industry. UP is suitable for all standard applications, especially glass fiber reinforced polymers and is less expensive. EP is used for high strength components such as carbon fiber reinforced polymers, but is relatively expensive. VE and PF resins, conversely, are rarely used for building components.

According to Table 2 and (Knippers et al., 2011), it can be concluded that two combinations are most suitable for buildings and façades, i.e. Glass Fiber Reinforced Polymer (GFRP) composites, which uses unsaturated polyester resin and Carbon Fiber Reinforced Polymer (CFRP), which uses epoxy resin.

Some major differences, however, must be highlighted between CFRP and GFRP composites for applications in building façades. GFRP, for example, is relatively inexpensive, an cost is often a deterrent for design choices. In addition, while CFRP is relatively stronger, GFRP is more suitable to be used as an exterior material, due to its typically low moisture absorption, which makes it more resistant to weather aggressions. This feature has a further implicit advantage, since during manufacturing the curing process will be significantly faster. As such, GFRP composites are typically preferred for construction systems.

\section{GFRP Composites in Building Façades}

When comparing the mechanical properties of carbon or glass fiber reinforced polymers with other traditional materials for buildings, some features - such as the ultimate strength, the elastic modulus or the maximum strain at failure, the material density - can have a key role in design considerations.

In Table 3 and Fig. 3, some mean mechanical properties as well as the stress-strain constitutive laws of GFRP, steel and aluminum are compared. GFRP is lighter than steel and even aluminum, which adds up to its mechanical performance. The ultimate strength of GFRP is almost equivalent to that of steel, but the elastic modulus is much lower, i.e. in the order of 4-5 times. The strain at failure for GFRP, on the other hand, is in the order of $1.5 \%$, hence resulting in a typically brittle failure mechanism compared to steel.

Besides being lighter than steel, GFRP has several additional advantages over traditional building materials. It is corrosion resistant and has low moisture absorption, therefore making it an ideal material for exterior use. GFRP is also nonconductive for electricity and has a typically low thermal conductivity (i.e. in the same order of wood), which makes it - although the thermal properties of FRP composites typically vary depending on the fiber orientation, configuration and volume fraction (see for example (Joven et al., 2012; Dong et al., 2016; etc.)) - an excellent insulation component for façades.

GFRP composites, according to (Knippers et al., 2011), have also a low level of embodied energy, which means that the energy required to manufacture a structural or architectural component from GFRP is markedly lower than in the case of a steel assembly. 
Table 3. Mechanical properties of GFRP composites, compared to steel and aluminum (Knippers et al., 2011)

\begin{tabular}{|c|c|c|c|}
\hline Property/material & GFRP & Steel & Aluminum \\
\hline Density $\left[\mathrm{g} / \mathrm{cm}^{3}\right]$ & 2.00 & 7.8 & 2.7 \\
\hline Ultimate strength $[\mathrm{MPa}]$ & 400.00 & 360.0 & 200.0 \\
\hline Elastic modulus [GPa] & 40.00 & 210.0 & 70.0 \\
\hline Strain at failure $[\%]$ & 1.50 & 25.0 & 15.0 \\
\hline Thermal conductivity $\left[\mathrm{W} / \mathrm{m}^{2} \mathrm{~K}\right]$ & 0.35 & 50.0 & 160.0 \\
\hline Coefficient of thermal expansion $\left[10^{-6} / \mathrm{K}\right]$ & 9.00 & 12.0 & 23.0 \\
\hline
\end{tabular}

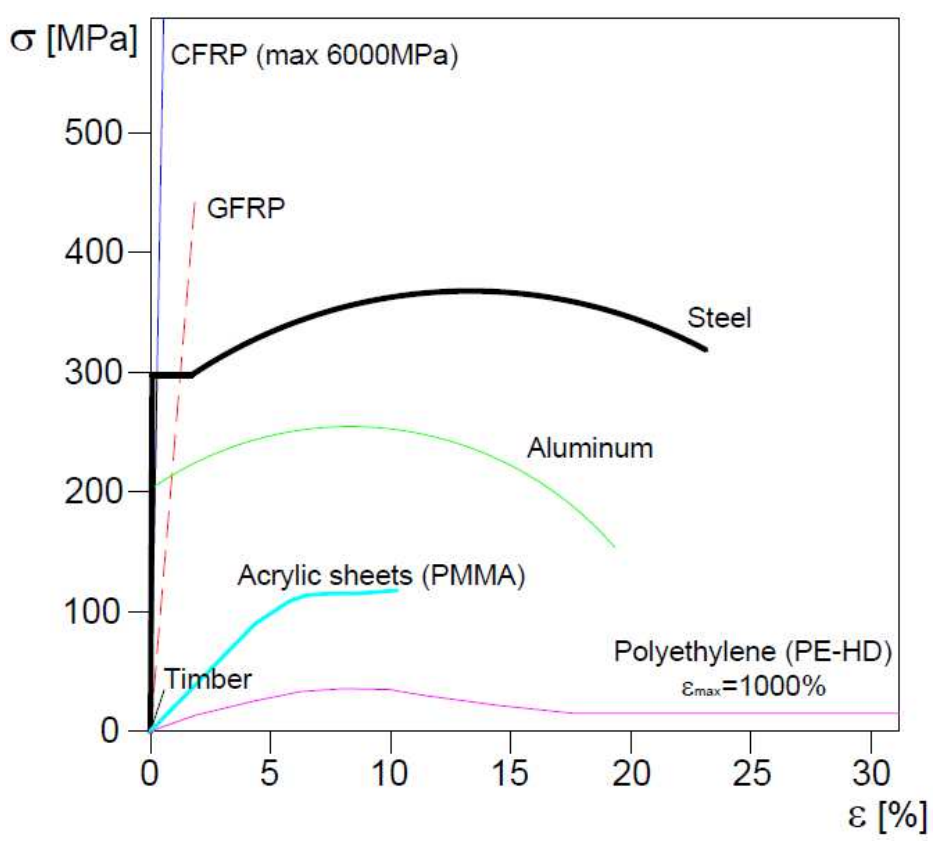

Fig. 3. Comparison of stress-strain constitutive laws for GFRP composites, compared to traditional structural elements for buildings (Knippers et al., 2011)

Lastly, GFRP components are characterized by high durability, hence requiring limited maintenance than traditional building materials such as wood, steel or aluminum. The intrinsic advantage of the resistance of GFRP composites to weather aggression and other types of corrosion agents, is that GFRP composites do not need a finishing protective layer (see also Kendal, 2007; Hollaway, 2008; van den Einde et al., 2003; Phol, 2010).

\section{Façade Retrofitting}

When talking about FRP retrofitting of façades, the typical application in the mind of the reader is generally represented by FRP jackets, strips and injections for reinforced concrete or masonry walls.

In the last years, a wide number of researchers already explored via experimental tests and/or Finite Element numerical simulations the efficiency of such solutions, giving evidence of their potential in steel and steel-concrete structures (i.e. Linde et al., 2014; Kamruzzaman et al., 2014; Liu et al., 2001; etc.), precast or cast-in-situ reinforced concrete systems (i.e. FIB, 2006; Promis et al., 2009; etc.), masonry (i.e. Moon et al.,
2002; Sivaraja et al., 2013; Bischof and Suter, 2014; Gattesco and Boem, 2015; etc.) as well as timber buildings (i.e. Zhang et al., 2014; Corradi et al., 2015; Bru et al., 2016; etc.).

\section{Reinforced Concrete and Masonry Façades}

The use of FRP jackets and strengthening components for the retrofitting of reinforced concrete or masonry structures has been extensively explored by researchers since the early 1990s. Up to current days, the further improvement of technological production, as well as continuous research efforts, lead to additional optimization of relatively recent design concepts and techniques.

Regarding some applications in building façades, in Mc Cuaig et al. (2008), for example, GFRP injections were used to retrofit the modular windows and restore the functionality of the precast concrete mullion units of a Toronto school, USA, see Fig. 4. Additional laboratory experiments demonstrated the capacity of GFRP wraps to enhance the ultimate state stiffness and ductility of the unreinforced precast concrete mullion, giving in situ restored functionality to the school building. 


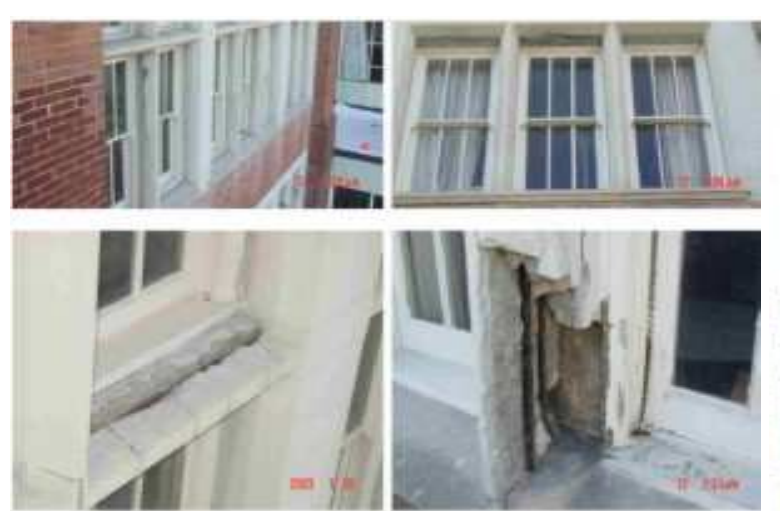

(a)

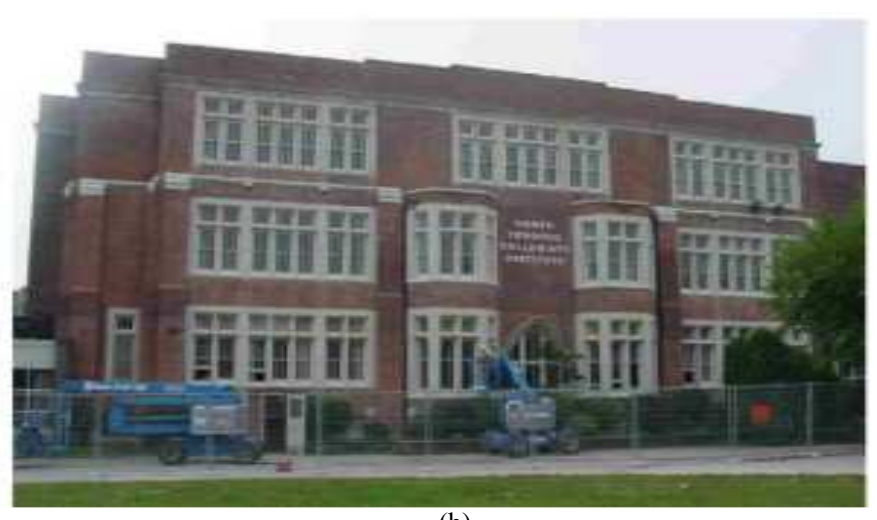

(b)

Fig. 4. GFRP retrofitting of a school building in Toronto. (a) example of cracks and severe damage in the (b) overview of the historic building after retrofitting (pictures taken from (Mc Cuaig et al., 2008))

Compared to the unreinforced precast mullion specimens, the FRP retrofitting wraps prevented major fractures in concrete and buckling of the steel reinforcement, resulting in a flexural strength enhancement and in a ductile failure mechanism for the tested retrofitted specimens.

Gattulli et al. (2014) recently proposed the retrofitting of a masonry building of historical importance located in Italy, namely the Camponeschi Palace in the city of L'Aquila (Italy), via CFRP and GFRP strips. The authors presented an accurate and efficient numerical modelling of FRP-reinforced masonry structures, as well as a refined investigation of the effects on the examined case study due to the 2009 earthquake of L'Aquila. Based on the so validated numerical modeling approach, the effectiveness of CFRP and GFRP strips for the enhancement of the inplane seismic performance of historical masonry walls belonging to a geometrically complex building system were critically discussed.

\section{Blast Resistance Enhancement of Façades}

FRP composites and textiles can be efficient also in the case of building façades subjected to exceptional loads, such as explosive events, both in the case of concrete as well as for masonry structural systems. Following the major terroristic attacks of New York (2001) up to London (2005), the early 2000s highlighted a huge number of research studies dedicated to the blast resistance of FRP composites for the reinforcement of concrete or masonry walls and façades, as well as slabs, beams and columns in general. Aiming to enhance the blast resistance and minimize the vulnerability of civilian facilities or critical structures (i.e. government, military, corporate buildings), experimental and FiniteElement numerical studies have been focused on the avoidance of blast induced structural damages, in conjunction with a preservation of the building appearance, especially in the case of historical buildings. A detailed state-of-the art review was proposed by Buchan and Chen (2007).

A more recent example can be found in (Georgakopoulos and Koklanos, 2012), where the potential of FRP or geotextile fabrics for the mitigation of blast induced effects on historic masonry building façades has been assessed. While on one side the major advantage of such retrofit solutions is given by the preservation of the aesthetic qualities of the historic building façade, FRP laminates and geotextile fabrics provide different behaviors and require specific design and construction considerations. FRP laminates typically provide high tensile strength and flexural capacity to the unreinforced masonry façade. On the other hand, geotextile fabrics are especially effective in the form of debris-catch systems, allowing to improve the dynamic response of the masonry façade as well as to protect the building surroundings and people from debris. The efficiency and criticalities of both the approaches have been critically discussed, including anchorage detailing and construction aspects, as well as architectural implications.

\section{FRP Composites in Façades - A Brief Summary of some Recent Case Studies}

Despite the huge use of FRP composites for the retrofitting of building façades, the last years highlighted a continuously increasing application of FRPs in façades as cladding systems, solar protection components as well as adaptable shading systems. Some case studies are briefly recalled in the following paragraphs.

\section{SFMOMA Façade}

The San Francisco Museum of Modern Art expansion (SFMOMA, San Francisco, CA, USA) - consisting in a façade composed of more than 700, uniquely shaped 
panels, most of them $1.5 \mathrm{~m}$ wide by $9 \mathrm{~m}$ long, for a total surface of $\sim 7800 \mathrm{~m}^{2}$ on a 10-story building - was designed by Snǿhetta starting from 2010 (www.snohetta.com) and the project broke ground in May 2013, with final conclusion in early 2016. FRP panels were used to form rippled patterns, influence (see Fig. 5d) by the topography, water and for of San Francisco bay. All these panels were affixed to a curtain wall system to create rippling horizontal blands. Additional silicate crystals embedded in the surface of the panels catch the changing light and cause the façade to shift in appearance through the day.

The expansion received a lot of press, for several reasons (see for example Gardiner, 2015a; 2015b). It was in any case, to date, the largest architectural use of FRP composites in a building project. Additionally, the FRP composite façade solution passed for the first time the rigorous USA fire-regulation testing that permits its use above the fourth story on a high-rise exterior (Gardner, 2015a).

\section{Shading Protection Fins - BBVA Headquarters}

Another recent example of use of FRP composites in tall buildings and towers is represented by the Banco Bilbao Vizcaya Argentaria (BBVA) Headquarters in Madrid, Spain and designed by Herzog and De Meuron (www.herzogdemeuron.com), see Fig. 6.

As also described in (Jesus Cerezo and Nunez Diaz, 2015), a 100m high building with a main façade consisting of a traditional curtain wall system was designed and equipped by an external solar protection system composed of FRP fins with $10 \mathrm{~m}$ height and $2.5 \mathrm{~m}$ width, $210 \mathrm{~mm}$ in thickness. The main feature is that each one of the FRP fins were built as unique pieces and self-supporting elements without internal joints. Careful consideration in their design was thus given by geometrical, constructional and functional requirements, as well as to purely structural needs, being the shading system required to support itself as well as the external wind loads.

Each fin is then reinforced by an inner structural frame of steel tubes, able to offer appropriate stiffness to the fins themselves as well as to distribute the external loads to the anchoring systems. A glued structural bonding provides the interaction between the FRP composites and the supporting steel tubes.

Wind tunnels and Finite Element numerical simulations proved the efficiency of such fins against the design wind loads, as well as thermal phenomena.

\section{Flectofin ${ }^{\circledR}$ Shading System for Adaptive Façades}

Adaptive façades are multi-parameter high performance envelopes that, opposite to fixed façades, react mechanically or chemically to external climate dynamically to meet internal loads and occupant needs (Luible, 2014, www.tu1403.eu). In the same way, adaptive shading systems in architecture generally refer to deployable structures which have the ability to respond to changing environmental conditions (e.g. solar radiation) by mediating external loads and internal demands (e.g. light incidence).

Within the existing adaptive façades (see for example (Attia et al., 2015) for an initial assessment review), an FRP composite adaptive shading system for free-form façades has been developed in (Schleicher et al., 2011a; 2011b; Lienhard et al., 2011). Taking advantage of bioinspired elastic kinematics, a hinge-less flapping mechanism inspired by the typical deformation principle of the Bird-of-Paradise flower, namely the Strelitzia reginae flower, has been proposed and patented in 2012 (see Figs. $7 \mathrm{a}$ and $7 \mathrm{~b}$ ). The potential of the so obtained Flectofin ${ }^{\circledR}$ shading system, compared to traditional, rigid-link flapping mechanisms of use in façades, is given by its intrinsic adaptability, as obtained from elastic deflection of material. In this context, a key role is given to FRP laminates, able to combine high tensile strength with low bending stiffness, hence offering an extremely wide range of calibrated elastic deformation configurations for load bearing structural systems. The Flectofin ${ }^{\circledR}$ shading system proved in fact to represent an efficient plant-like, hinge-less adaptive mechanism for architectural applications.

The preliminary investigations, as also highlighted in (Schleicher et al., 2011a; 2011b; Lienhard et al., 2011) confirmed the high potential of FRPs, compared to classical building materials like steel or aluminum, especially as a consequence of the intrinsic small stiffness-to-strength ratio, of FRP composites. The choice of glass fibers was then suggested by limited cost, compared to carbon fibers, high translucency and marked weather resistance, compared to aramid fibers.

The final application of the interdisciplinary research study presented in (Schleicher et al., 2011a; 2011b; Lienhard et al., 2011) found place in the biomimetic "One Ocean's" kinetic façade for the Theme Pavilion, as designed by Soma Architecture (www.somaarchitecture.com) for the Expo 2012 in Yeosu, South Korea and representing one of the major permanent pavilions for that exhibition (see www.compositesandarchitecture.com and Fig. 7c). The main entrance and one side of the pavilion were characterized by a moving, convertible façade. More in detail, a façade covering a total length of $140 \mathrm{~m}$ and a total height comprised between $3 \mathrm{~m}$ and $13 \mathrm{~m}$, consisting of 108 kinetic FRP lamellas, was designed. The lamellas are moved by actuators at the top and bottom edge of the FRP blade, which induce compression forces to create complex elastic deformations.

Besides the function to control light conditions (each lamella can be addressed individually with a specific movement, to obtain different choreographies and operation modes), the lamellas create animated patterns on the façade, including local movements as well as global waves on the total length of the pavilion. 


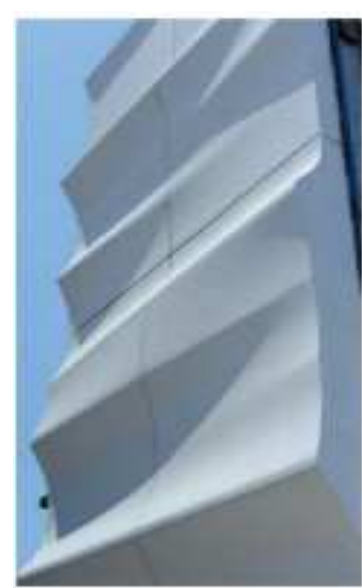

(a)

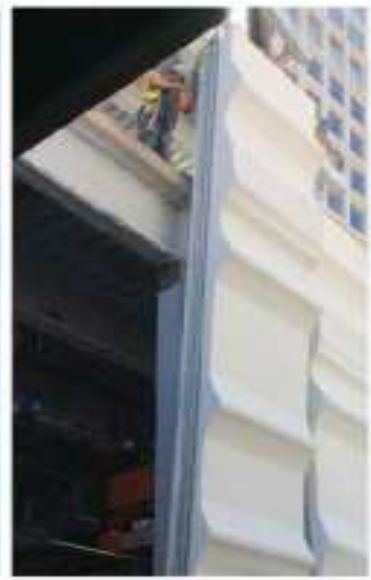

(b)

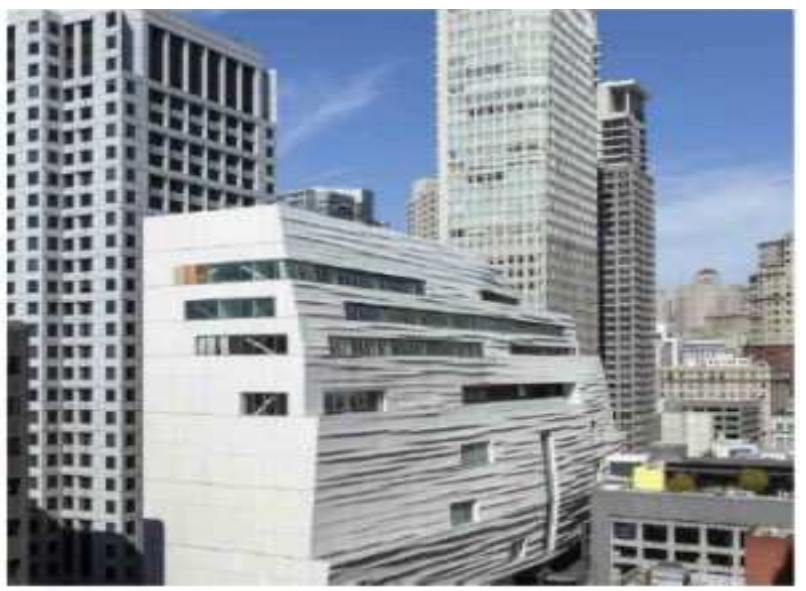

(c)

Fig. 5. SFMOMA expansion façade. (a)-(b) details of the construction phase and (c) overview of the building after conclusion of the renovation project (pictures taken from www.viamagazine.com)

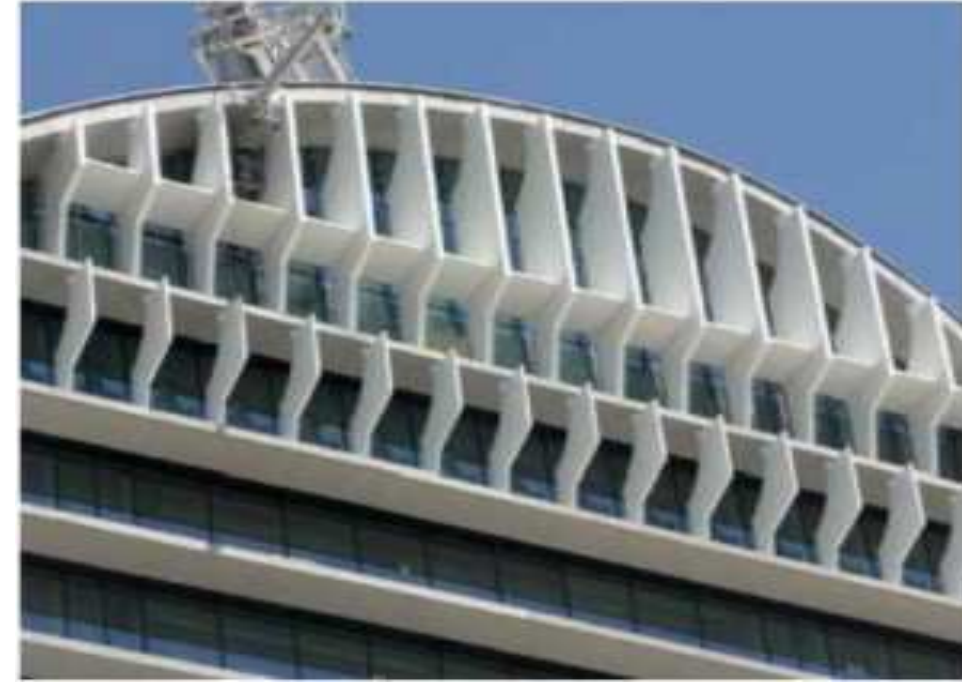

(a)

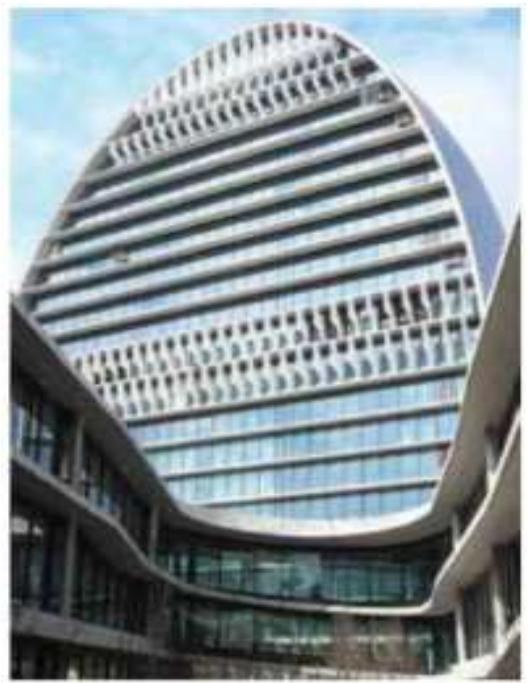

(b)

Fig. 6. FRP solar protection fins for the new BBVA Headquarters in Madrid, Spain. (a) Detail during construction and (b) overview of the finalized building façade

Ongoing Research on Novel FRP Façades and allin-One Panels for Building Skins

Very recent trends of architecture and engineering are emphasizing the use of FRP in building skins for all-inone sandwich panels to be used in unitized façades, as well as the use of FRP pultruded members to replace traditional aluminum or steel frames and interact with glazing (see for example Fig. 8 and (Glaströsch, 2016)).

\section{FRP Composites and Glazing Façade Modules}

Several research studies already highlighted the high potential of FRP composited to be used in façade modular units, in place of traditional metal frames. Jin et al. (2009), for example, investigated the energy efficiency of a cellular panel for FRP façade modules consisting of glazing, spandrel panels, mullions and joints. In that literature contribution, a structural optimisation was first achieved, in order to define the most efficient cross-section of the spandrel panel. Thermal analyses are then carried out on the same system, giving evidence of the thermal insulation and translucency potentials, compared to the actual standard requirements. The study highlighted the feasibility of such system, but also emphasized - especially from a thermal point of view - the joints as the critical component of the so assembled FRP façade modular units. 


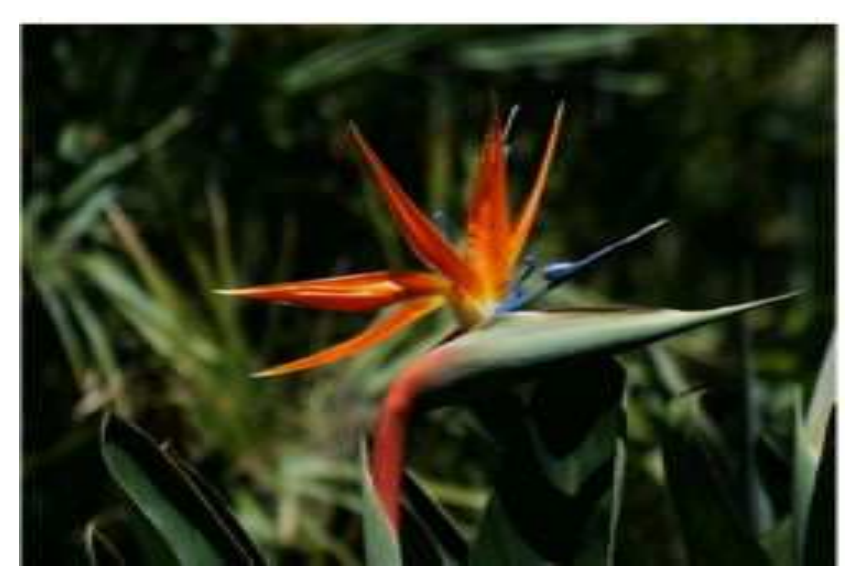

(a)

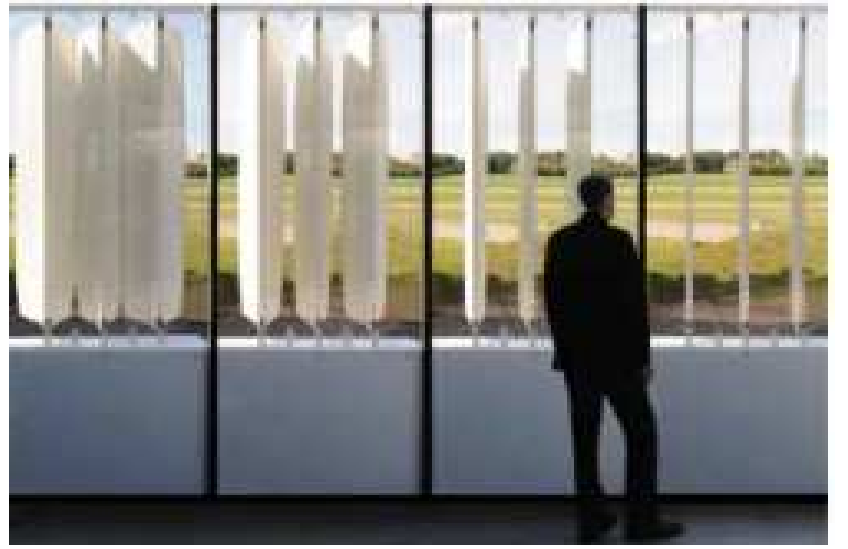

(b)

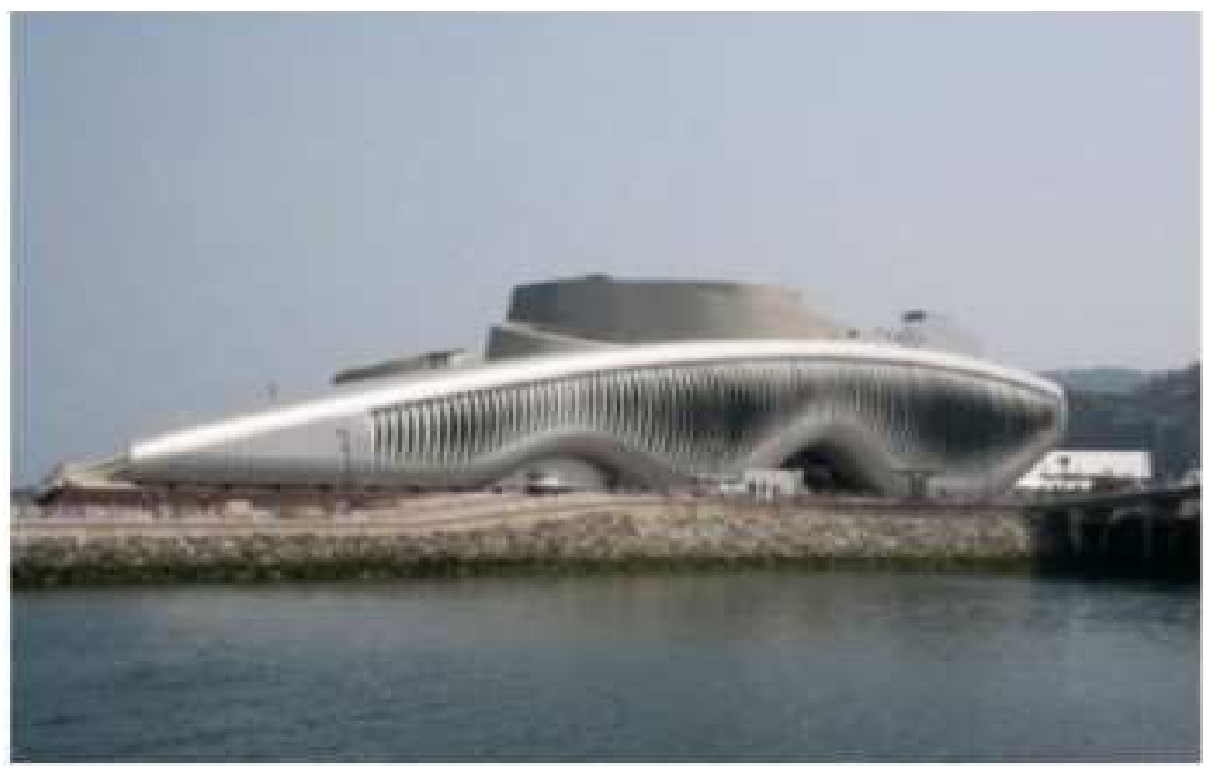

(c)

Fig. 7. Flectofin ${ }^{\circledR}$ shading systems for adaptive façades. (a) the Bird-of-Paradise flower (source: www.asknature.com) (b) full scale prototype for the Flectofin ${ }^{\circledR}$ principle (picture taken from (Lienhard et al., 2011)); (c) the Theme Pavilion for Expo 2012 in Yesou. South Korea, by Soma Architecture (source: www.compositesandarchitecture.com)

A further investigation effort is currently going on at University of Cambridge, UK, Department of Engineering, (GFT-Glass \& Façade Technology research group, www.gft.eng.cam.ac.uk) to explore and optimize - in terms of structural and thermal performance, as well as transparency, durability and fabrication cost - an adhesively bonded GFRP-glass composite sandwich panel (see Fig. 9 and for example (Cordero et al., 2015; Overend and Benson, 2014; GFT, 2016)).

Taking advantage of this design concept - compared to actual GFRP-glass design solutions (i.e. Fig. 8) daylight is allowed and the GFRP frame is efficiently protected from weathering. The thermal performance of the building envelope is hence also strongly improved, due to the presence of the air cavity between the glazing sheets. The final aim of this ongoing project is to develop a novel GFRP-glass sandwich structural concept for transparent building envelopes. The concept itself represents a radical shift in the use of glass in buildings, i.e. from a current use as infill panel supported by thermally inefficient metallic profiles or GFRP pultruded profiles (i.e. Fig. 8) towards a loadbearing component integrated in a thermally efficient sandwich unit. Based on the current outcomes, the new concept under investigation already proved in fact to offer potential for reducing weight and depth of the typical unitised modular unit, as well as for increasing transparency and thermal performance of building envelopes compared to actual glass façade systems. 


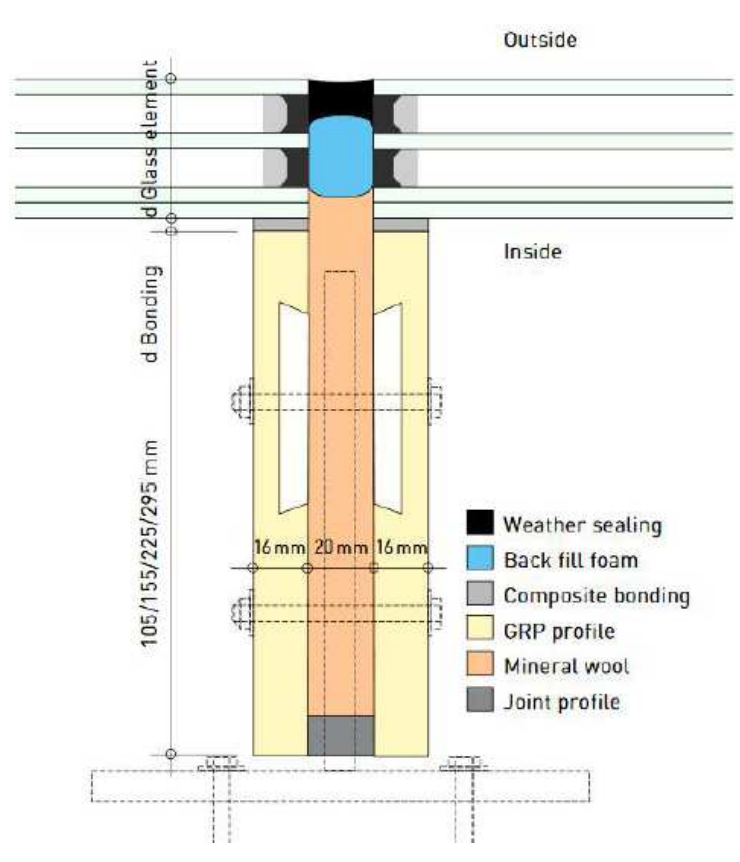

Fig. 8. Typical cross-section of a unitised GFRP-glass curtain wall with pultruded mullions ((source: Glaströsch 2016), www.glasstroesch.ch)

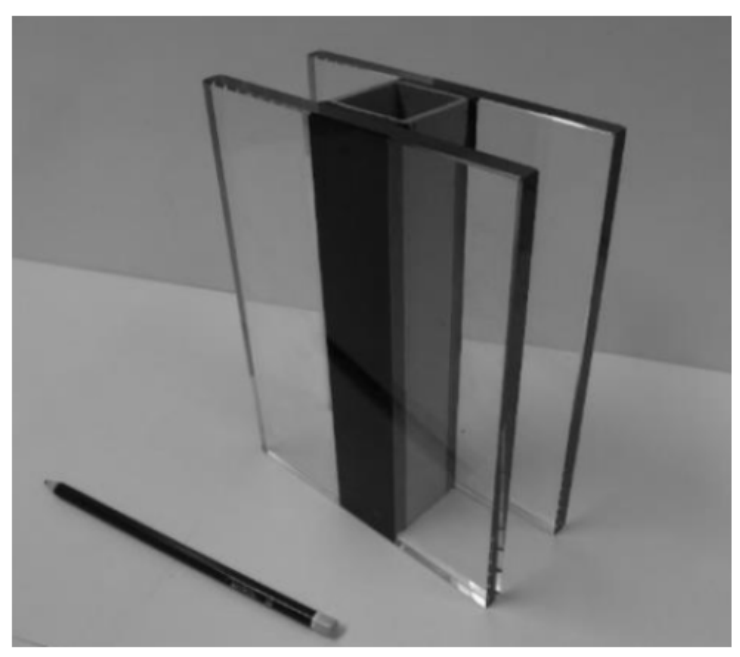

Fig. 9. Adhesively bonded GFRP-glass sandwich panels (source: www.gft.eng.cam.ac.uk)

\section{All-in-one FRP Sandwich Panels for Unitized Façades}

Within the currently available methods for the construction of FRP unitised façades, two major general approaches can be distinguished. The first method consists in the assembly of the façade elements based on multiple components (i.e. the glazing panels and the FRP composite profiles, see Fig. 8 ), as also briefly discussed in the previous section.

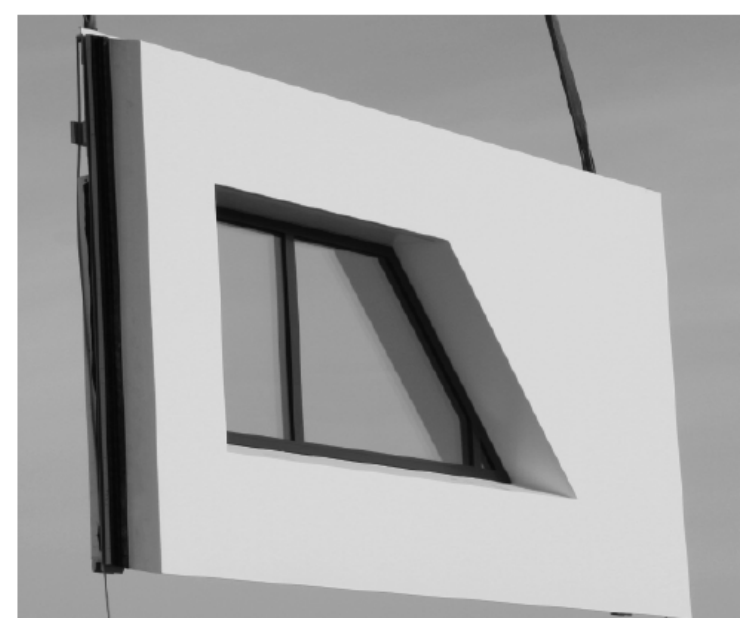

Fig. 10. Example of all-in-one FRP sandwich panel (Rietbroek 2013)

This fabrication process is mostly similar to the traditional fabrication process for aluminum or steel frame unitised façade systems.

The second method, deeply investigated in (Rietbroek, 2013), see Fig. 10, consists in the production of entire façade elements in the form of one major (monolithic) FRP composite panel, based on a single production process. In accordance with this second approach, the so assembled FRP composite sandwich element provides both the bearing framework of the building façade as well as the insulation infill contribution, although being composed of one component only.

As discussed by Rietbroek (2013), the basic idea and key concept behind all-in-one FRP unitised façade elements is that they can be fully produced and assembled off-site. After transportation, these elements are mounted on the building bearing structure, hence providing an instantly finished façade.

A primary direct effect of this system typology is that the installation speed of the façade is very high, compared to the traditional fabrication approach for unitised façades. Since the FRP panels are produced and assembled in controlled environment conditions, the quality of the façade elements is also generally high. In addition, since a typical monolithic FRP composite panel consists of one major part only, the amount of mechanical connections and gaskets or spacers is significantly lower, compared to other façade systems.

Despite these advantages, additional components are however required for the appropriate fulfillment of a complete unitised façade sandwich panel. A critical aspect, in this sense, is first represented by the presence of one or more window openings that need to be installed in such sandwich panels. A sealant connection needs also to be applied along the FRP panel edges, so that the single adjacent panels could be properly connected to each other, as well as a weather-tight façade could be provided. 
Although further studies are still required for this novel design concept, Rietbroek (2013) concluded by confirming the feasibility and potential of such solution. Well promising results emerged from the investigations and some design recommendations were also provided towards the full optimization of the concept.

\section{Conclusion}

FRP composites are largely used in the automotive, marine, industrial or ballistic sectors since several decades, but found increasingly applications in civil engineering buildings and infrastructures only from the late 1990s. Major applications of FRP composites in buildings, since that period, can be found especially in the form of jackets, strips or wraps for the retrofitting of existing buildings composed of traditional materials, such as masonry, reinforced concrete, timber or steel.

The current trends of architectural design are showing, however, a marked increase of FRP applications in building façades and skins, both in the form of all-in-one cladding panels, load-bearing pultruded members or adaptive solar protection panels and movable shading systems.

In this review paper, a brief summary of the most recent applications of FRP composites in façades and building skins is provided, giving evidence of the variability of applications as well as of the intrinsic advantages of such materials, compared to traditional materials for buildings. The current design trends are also emphasized, via a short summary of some case studies as well as ongoing research projects.

\section{Ethics}

The Author declares that there is no conflict of interest.

\section{References}

Attia, S., Favoino, F., Loonen, R. Petrovski A., and Monge-Barrio, A., 2015. Adaptive façades system assessment: An initial review. Proceedings of the 10th Conference Advanced Building Skins, Nov. 3-4, Bern, Switzerland, pp: 1275-1283.

Bischof, P., and Suter, R., 2014. Retrofitting masonry walls with carbon mesh. Polymers, 6: 280-299. DOI: $10.3390 /$ polym6020280

Bru, D., J. Baeza, F.B. Varona, J. Garcia-Barba, and S. Ivorra, 2016. Static and dynamic properties of retrofitted timber beams using glass fiber reinforced polymers. Materials Structures, 49: 181-191.

Buchan, P.A., and Chen, J.F., 2007. Blast resistance of FRP composites and polymer strengthened concrete and masonry structures-A state-of-the-art review. Composites Part B, 38: 509-522.
Cordero, B., Santos, A.G., and Overend, M., 2015. Thermal performance of novel frame-integrated unitised curtain wall. Revista de la Construccion, 14: 23-32.

Corradi, M., Righetti. L., and Borri, A., 2015. Bond strength of composite CFRP reinforcing bars in timber. Materials, 8: 4034-4049.

DOI: $10.3390 / \mathrm{ma} 8074034$

Dong, K., Gu, B., and Sun, B.J., 2016. Comparison of thermal conductive behaviors of epoxy resin in unidirectional composite materials. J. Thermal Analysis Calorimetry, 124: 775-789.

FIB, 2006. Retrofitting of concrete structures by externally bonded FRPs with emphasis on seismic applications. Fédération Internationale du Béton (FIB), ISBN-10: 2-88394-075-4.

Gardiner, G., 2015a. The building envelope: FRP unitized facades. www.compositesworld.com

Gardiner, G., 2015b. SFMOMA façade: Advancing the art of high-rise FRP. Composite Technology. www.compositesworld.com

Gates, P., Ibell, T., Darby, A., Evernded, M., and Kragh, M. 2012. Advanced composites for façade retrofit. Structural Engineer.

Gattesco, N., and Boem, I., 2015. Seismic enhancement of masonry buildings strengthened through GFRP reinforced mortar coating. Applied Mechanics Materials, 796: 53-67.

DOI: 10.4028/www.scientific.net/AMM.796.53

Gattulli, V., Lampis, G., Marcari, G., and Paolone, A., 2014. Simulations of FRP reinforcement in masonry panels and application to a historic facade. Engineering Structures, 75: 604-418.

Georgakopoulos, P., and Koklanos, P., 2012. Design, detailing and architectural impacts of Fiber Reinforced Polymers (FRP) and geotextile fabrics in the blast mitigation of unreinforced masonry walls in historic buildings. Proceedings of the Structures Congress, March 29-31, Chicago, IL, USA.

GFT-Glass and Façade Technology Research Group, 2016. Bi-annual research newsletter.

Glaströsch, 2016. Composite Glazing-The unique building skin made from glass-fibre elements and glass.

Jesus Cerezo, M., and Nunez Diaz, M.A., 2015. Fiber Reinforced Polymer (FRP): A new material used in facades of tall buildings. Proceedings of CTBUH 2015 New York Conference, pp.636-644

Jin, Q., Overend, M., and Kragh, M., 2009. The performance and optimisation of a novel façade panel for energy-efficient buildings. Proceedings of the CISBAT Conference, Lausanne, Switzerland.

Joven, R., Das, R., Ahmed, A., Roozbehjavan, P., and Minaie, B., 2012. Thermal properties of carbon fiberepoxy composites with different fabric waves. 
Proceedings of the SAMPE International Symposium, Charleston, SC, USA.

Kamruzzaman, M., Jumaat, M.Z., Ramli Sulong, N.H. and Saiful Islam, A.B.M. 2014. A review on strengthening steel beams using FRP under fatigue. Scientific World J., DOI: 10.1155/2014/702537

Kendal, D., 2007. Building the future with FRP composites. Reinforced plastics. Philadelphia: Elsevier.

Knippers, J., Cremers, J, Gabler, M., and Lienhard, J., 2011. Construction manual for polymers + membranes. Berlin: Birkhauser

Hollaway, L.C., 2010. Polymer Composites. In: Construction Materials: Their Nature and Behaviour, Domone, P.L., and Illston, J.M. (Eds)., New-York: Spon Press, pp: 319-364.

Lienhard, J., Schleicher, S., Poppinga, S., Masselter, T., and Milwich, M., 2011. Flectofin: A hingeless flapping mechanism inspired by nature. Bioinspiration Biometrics.

Linde, J.K., Tait, M.J., El Dakhakhni, W.W., and Razavi, S.N., 2014. FRP-confined concrete composite retrofit system for structural steel columns. J. Composites Construction, 19:

DOI: $10.1061 /(A S C E) C C .1943-5614.0000543$

Liu, X., Silva, P.F., and Nanni, A., 2001. Rehabilitation of steel bridge members with FRP composite materials. Proceedings of the CCC2001 Conference Composites in Construction, Oct. 10-12, Porto, Portugal, pp: 613-617.

Luible, A., 2014. Memorandum of Understanding for the implementation of a European Concerted Research Action designated as COST Action TU1403: Adaptive Facades Network. www.tu1403.eu

Moon, F., Yi, T., Leon, R., and Kahn, L., 2002. Retrofit of unreinforced masonry structures with FRP overlays and post-tensioning. Proceedings of the Conference Rehabilitating and Repairing the Building and Bridges of Americas, Mayaguez, Puerto Rico, USA, pp: 20-36. DOI: 10.1061/40613/272)3

Mc Cuaig, L., Reginato, L., and Soudki, K., 2008. GFRP retrofit for facades in a Toronto school. Construction Building Materials, 22: 61-69.
Overend, M., and Bensonk, S., 2014. GFRP-glass composite structures. Innovation Research Focus, 98: 5-5.

Paparo, I., Overend, M., and Micoli, F., 2015. Performance-based material selection and design for freeform building envelopes. Proc. Advanced Building Skins.

Phol, G., 2010. Textile, polymers and composites for buildings. Sawston: Woodhead Publishing.

Promis, G., Ferrier, E., and Hamelin, P., 2009. Effect of external FRP retrofitting on reinforced concrete short columns for seismic strengthening. Composite Structures, 88: 367-379.

Rietbroek, A.J.T., 2013. Next Generation Facades - An analysis on the design and production of monolithic FRP composite sandwich elements for unitised façade systems. MSc Thesis, TU Delft, The Netherlands.

Sivaraja, S.S., Thandavamoorthy, T.S., Vijayakumar, S., and Aranganathan, S.M., 2013. Preservation of historical monumental structures using Fiber Reinforced Polymer (FRP) case studies. Procedia. Eng., 54: 472-479.

Schleicher, S., Lienhard, J., Knippers, J., Poppinga, S., and Masselter, T., 2011a. Bio-inspired kinematics for adaptive shading systems on free form facades. Proceedings of the IABSE-IASS Symposium "Taller Longer Lighter", London, UK.

Schleicher, S., Lienhard, J., Knippers, J., Poppinga, S., and Masselter, T., 2011b. Adaptive façade shading system inspired by natural kinematics. Proceedings of the International Adaptive Architecture Conference, March 2011, Building Centre-London, UK.

van den Einde, L., Zhao, L., and Seible, F., 2003. Use of FRP Composites in Civil Structural Applications. Construction and Building Materials. 17th Edn., Philadelphia: Elsevier.

Zhang, W., Song, W., Gu, X., and Tang, H., 2012. Compressive behavior of longitudinally cracked timber columns retrofitted using FRP sheets. J. Structural Eng., 138: 90-98.

DOI: 10.1061/(ASCE)ST.1943-541X.0000423 